\title{
Orbital myxoma. Report of an unusual case
}

\section{Mixoma orbitario. Reporte de un caso inusual}

Lourdes Rodríguez-Cabrera*, Francisca Zuazo, Oliver Schneider-Ehrenberg, Adriana Moreno-García and José Luis Tovilla-Canales

Instituto de Oftalmología Fundación de Asistencia Privada Conde de Valenciana IAP, Mexico City, Mexico

\begin{abstract}
Myxomas are rare, benign tumors of mesenchymal origin, which can be found in skin, heart, subcutaneous tissue and bone. Here, we describe the case of an orbital myxoma and present its clinical and imaging characteristics, as well as the surgical approach and histopathological description that led us to the diagnosis. The case involves a forty-year-old male with a 5-month history of progressive swelling in the inner third of the left lower eyelid. Previously, the patient had undergone resection of a tumor in the same region with a histopathological diagnosis of rhabdomyosarcoma. On examination a soft, mobile, painless mass was found in the inner third of the left lower eyelid that did not change with the Valsalva maneuver. Computed tomography showed a homogeneous extraconal lesion, similar to the density of the vitreous, well-defined edges, in the anterior and inferonasal portion of the left orbit. An excisional biopsy was performed, and subsequent histopathological examination showed fusiform cells without nuclear atypia and an abundant myxoid stroma. Immunohistochemistry was positive for vimentin and S-100. This led to the diagnosis of orbital myxoma. After surgery, the patient progressed well and was asymptomatic and without tumor recurrence.
\end{abstract}

Key words: Orbital neoplasia. Connective tissue neoplasm. Orbital myxoma. Rhabdomyosarcoma. Immunohistochemistry. Vimentin.

\section{Resumen}

Los mixomas son neoplasias poco frecuentes, benignas, de origen mesenquimatoso, que se pueden encontrar en piel, corazón, tejido celular subcutáneo y hueso. En el presente artículo describimos el caso de un mixoma orbitario, presentando las características clínicas y de imagen; el abordaje quirúrgico y la descripción histopatológica que nos llevo al diagnóstico. Paciente masculino de 40 años de edad quien consultó por presentar aumento de volumen en el tercio interno del párpado inferior izquierdo de 5 meses de evolución. Anteriormente, se le había realizado la resección de una tumoración en la misma región, con diagnóstico histopatológico de rabdomiosarcoma. En la evaluación de los anexos oculares, se apreció una lesión de aspecto nodular, blanda, móvil, no dolorosa, en tercio interno del párpado inferior izquierdo, que no presentaba cambios con maniobras de Valsalva. La tomografía computada demostró una lesión extraconal homogénea, con densidad semejante a la del vítreo, con bordes bien definidos, en la porción anterior e inferonasal de la órbita izquierda. Se realizó biopsia escisional, cuya histopatología evidenció células fusiformes sin atipia nuclear con abundante estroma mixoide. Su inmunohistoquímica resultó positiva para vimentina y S-100. Con esto, se diagnosticó un mixoma orbitario. Tras la cirugía, el paciente evolucionó favorablemente, asintomático y sin recidiva de la lesión.

Palabras clave: Neoplasia orbitaria. Neoplasia de tejido conectivo. Mixoma orbitario. Rabdomiosarcoma. Inmunohistoquímica. Vimentina.

\section{Correspondence:}

*Lourdes Rodríguez-Cabrera

E-mail: lourdes_ocp@ hotmail.com
Date of reception: 28-09-2016

Date of acceptance: 21-11-2016

DOI: 10.24875/RMOE.M18000049
Available online: 11-01-2019 Rev Mex Oftalmol (Eng). 2019;93(1):35-38 www.rmo.com.mx

0187-4519/( 2018 Sociedad Mexicana de Oftalmología. Publicado por Permanyer México. Este es un artículo Open Access bajo la licencia CC BY-NC-ND (http://creativecommons.org/licenses/by-nc-nd/4.0/). 


\section{Introduction}

Myxomas are rare mesenchymal neoplasms that usually originate in the heart, jaw bone, and limb muscles. They are benign, but locally infiltrative ${ }^{1}$ and destructive ${ }^{2}$. They are rarely located in or around the eyeball, either in the eyelids, conjunctiva, cornea, orbital bones or orbit ${ }^{3}$. The diagnosis requires histological confirmation when an excisional biopsy is performed ${ }^{4,5}$.

Here we describe the case of an orbital myxoma and present its clinical and imaging characteristics, as well as the surgical approach and histopathological description that led us to the diagnosis.

\section{Clinical case}

A 40-year-old male patient came to our clinic due to a 5 -month history of progressive volume increase of the inner third of the left lower eyelid. He denied any weight loss or other associated systemic symptoms.

He reported that 3 years before he had undergone a tumor resection in the same region, with a histopathological diagnosis of rhabdomyosarcoma at that time. However, he denied receiving any oncological treatment after this diagnosis.

On ophthalmic exam, a visual acuity of 20/20 was found in both eyes. Biomicroscopy and fundoscopy of both eyes were normal. Intraocular pressure was $14 \mathrm{mmHg}$ in both eyes. The pupillary reflexes, color vision and ocular motility were also normal.

When evaluating the ocular adnexa, a nodular, soft, mobile, non-painful lesion was observed in the inner third of the left lower eyelid, which did not change in color or size with Valsalva maneuver. The lesion did not displace the globe or erode through the conjunctiva.

A computed tomography showed a homogeneous extraconal lesion, with a density like that of the vitreous, with well-defined edges, in the anterior and inferonasal portion of the left orbit. There was no bone destruction or infiltration of adjacent structures such as the globe or muscles. The lesion did not enhance with contrast medium (Fig. 1).

An excisional biopsy was performed through an anterior orbitotomy with an inferior fornix approach. A 33 $\times 24 \times 31 \mathrm{~mm}$ multicystic lesion, grayish-white and with gelatinous consistency was excised and sent to histopathological study. There were no perioperative or postoperative complications.

Microscopically, the neoplasm showed regular, small and very uniform fusiform cells with sparse cytoplasm, and ovoid and regular nuclei. No atypia or mitosis were observed. The neoplasm showed an abundant myxoid stroma and contained few reticular fibers (Fig. 2). The edges of the excised tissue were negative for tumor cells.

Immunohistochemistry was negative for desmin and actin, and positive for vimentin and S-100. These findings led to a diagnosis of orbital myxoma.

With this diagnosis, a systemic work-up was performed, which was negative for myxoma of the heart, skin abnormalities, endocrine disorders or family history, among others, ruled out the diagnosis of Carney complex ${ }^{2,5}$.

After surgery, the patient had an adequate outcome with no relapse of the lesion and he remained asymptomatic eight years after surgery.

\section{Discussion}

Myxomas are benign and rare neoplasms, which can be found in the skin, heart, subcutaneous tissue and bone ${ }^{4,6}$. In 1948 Stout defined myxomas as neoplasms derived from primitive mesenchymal cells ${ }^{1,5,7}$. However, nowadays, these neoplasms are considered to be derived from cells that resemble altered fibroblasts and not from primitive mesenchymal cells ${ }^{1,5}$. Therefore, it has been proposed that their origin may include vascular endothelium, neural crest cells, dendritic cells, fibroblasts or their precursors ${ }^{5}$. Regardless of its origin, they are composed of mesenchymal cells that produce a large amount of glycosaminoglycans, rich in hyaluronic acid and with sparse collagen ${ }^{5}$.

Myxomas located in the orbit are extremely unusual ${ }^{2}$. These may involve the orbital soft tissue, the adjacent bone or extend from the paranasal sinuses into the orbit. ${ }^{5}$ Up to date, there are very few cases reported in the literature $e^{2,8,9}$.

They show a slow and expansive growth. Clinically they can cause proptosis and diplopia or manifest as a painless mass 4 .

In computed tomography they are described as solid, isodense, well-defined, multiloculated tumors that do not enhance with contrast medium ${ }^{10}$.

Histologically, they are described as hypocellular and hypovascular lesions ${ }^{5}$ with stellate or fusiform cells, with pyknotic nuclei, contained in an abundant myxoid or mucoid stroma, rich in hyaluronic acid ${ }^{4}$. Differential diagnoses should also include benign tumors with myxoid stroma ${ }^{5}$, such as myxolipomas, nerve sheath myxomas, or benign peripheral nerve sheath tumors such as neurofibromas and schwannomas; the latter, with positive immunoreactivity for S-100 3,5 . 


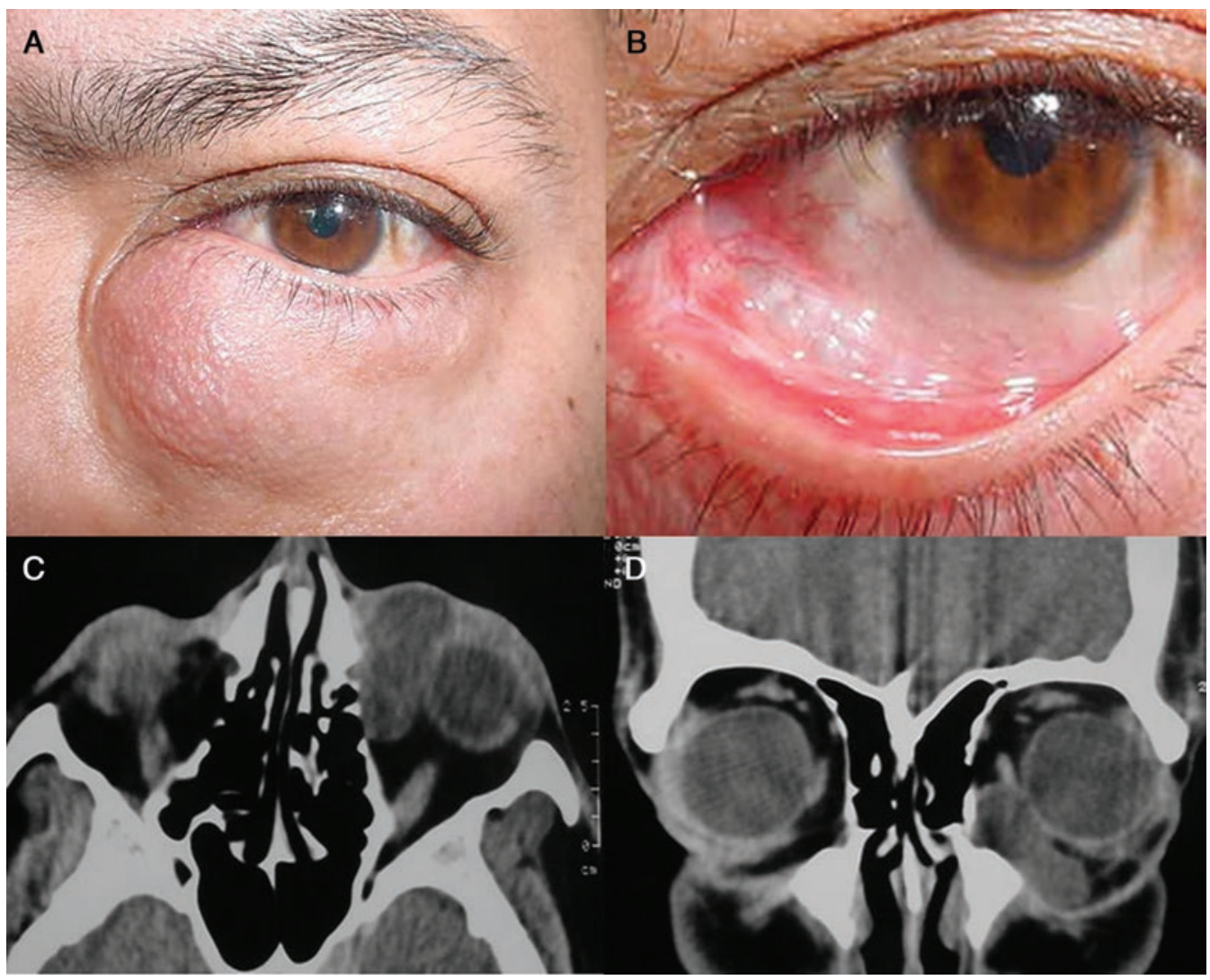

Figure 1. A and B: Mass with a nodular appearance in the inner third of the lower eyelid of the left eye. C and D: Computed tomography of the orbit showing a homogeneous extraconal lesion with a similar density to the vitreous. It does not destroy bone or infiltrate adjacent structures.

Their main differential diagnosis, however, are soft tissue sarcomas with myxoid degeneration ${ }^{1}$. The distinction between a benign myxoma and a sarcoma, mainly from a liposarcoma, rhabdomyosarcoma or less frequently from myxoid variants of malignant fibrous histiocytomas, can be very difficult, given the presence of abundant mucinous areas ${ }^{10}$. Generally, myxomatous variants of sarcomas have histological features of malignancy such as mitotic activity and nuclear pleomorphism, they show a higher cell content and more prominent vasculature ${ }^{10}$.

Immunohistochemistry shows high positivity for vimentin that aids in the diagnosis'.

Although it is a benign neoplasm, with a low malignant potential ${ }^{1}$, it can be locally destructive ${ }^{2}$. For this reason, the preferred treatment is wide surgical excision ${ }^{2-4}$, both for primary and recurrent lesions, since myxomas are radioresistant ${ }^{1}$.

With the previously described history, we believe that this case is a recurrent orbital myxoma. The presence of a previous histopathology compatible with an orbital rhabdomyosarcoma, treated only with surgery, with a prolonged remission before the current symptoms appeared, make us believe that the "rhabdomyosarcoma" was probably an orbital myxoma with abundant myxoid areas, that may have made it difficult to diagnose initially.

\section{Conclusion}

In conclusion, orbital myxomas are rare tumors that may represent a diagnostic challenge, therefore requiring an accurate clinical, histopathologic and immunohistochemistry diagnosis.

\section{Ethical disclosures}

Protection of human and animal subjects. The authors declare that no experiments were performed on humans or animals for this study.

Confidentiality of data. The authors declare that they have followed the protocols of their work center on the publication of patient data.

Right to privacy and informed consent. The authors declare that no patient data appear in this article. 


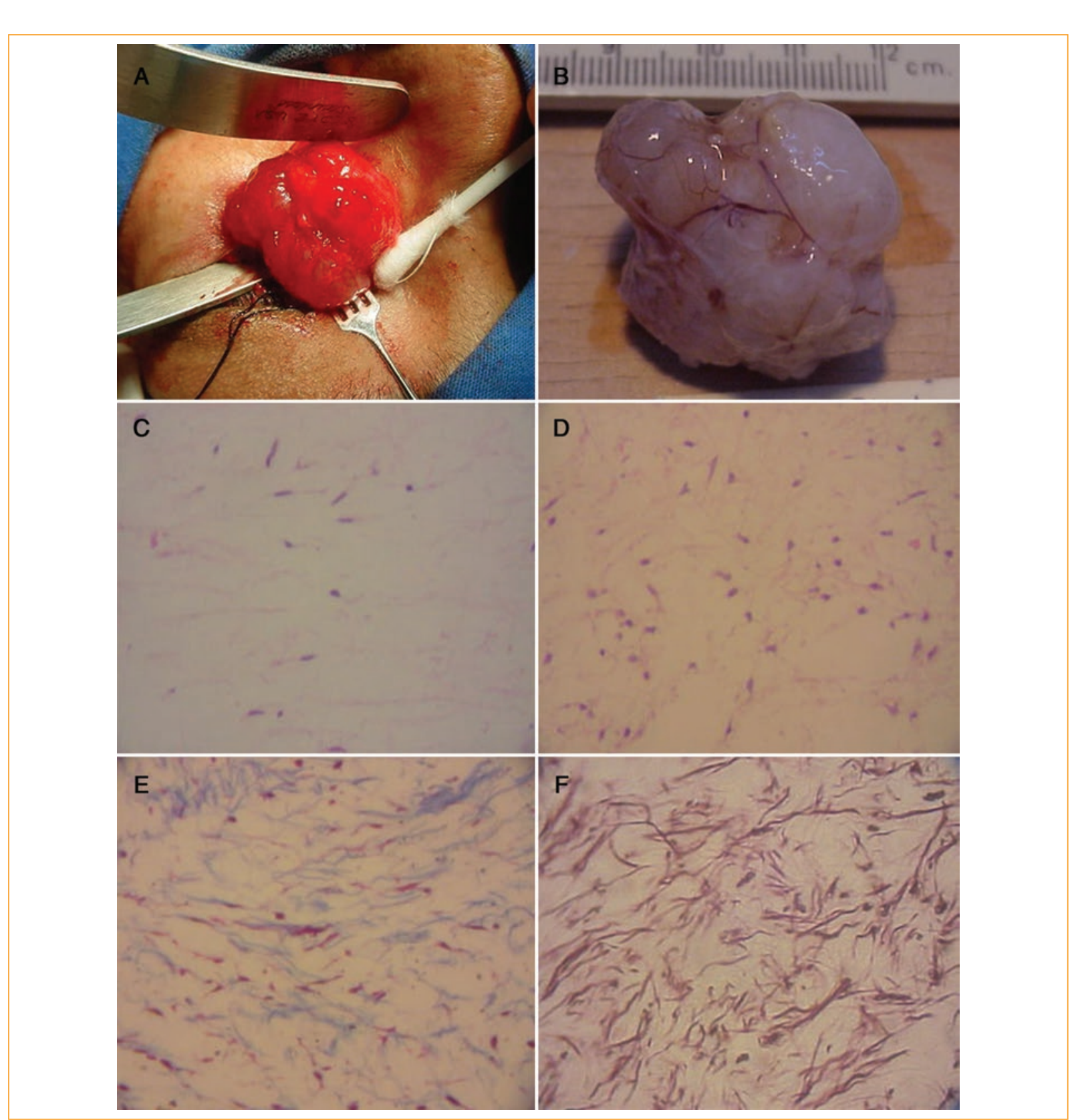

Figure 2. A and B: Intraoperative photography of the excisional biopsy showing a multicystic lesion.

C and D: Photomicrographs of hematoxylin and eosin stains from the myxomatous area show cells with an abundant mucinous matrix. E and F: Photomicrography with a higher magnification; stellate and fusiform cells of the myxoma are shown, with intracytoplasmic inclusions.

\section{Funding}

The authors received no specific funding for this work.

\section{Conflicts of interest}

The authors declare no conflicts of interest.

\section{References}

1. Tawfik HA, Elraey HZ. Orbital myxoma: A case report. Orbit. 2013;32:200-2.

2. Ting SL, Koay CL, Ngo CT, et al. Orbital myxoma-an unusual cause of inferoorbital mass. Med J Malaysia. 2010;65:224-6.
3. Bajaj MS, Mehta M, Kashyap S, et al. Clinical and pathologic profile of angiomyxomas of the orbit. Ophthal Plast Reconstr Surg.2011;27: 76-80.

4. Rambhatla S, Subramanian N, Gangadhara Sundar JK, et al. Myxoma of the orbit. Indian J Ophthalmol. 2003;51:85-7.

5. Hidayat AA, Flint A, Marentette L, et al. Myxomas and angiomyxomas of the orbit: A clinicopathologic study of 6 cases. Ophthalmology. 2007:114:1012-9.

6. Landa L, Hedrick M, Nepomuceno-Perez M, et al. Recurrent myxoma of the zygoma: A case report. J Oral Maxillofac Surg. 2002;60:704-8.

7. Stout AP. Myxoma, the tumor of primitive mesenchyme. Ann Surg. 1948; 127:706-9.

8. Mani NB, Shankar S, Singh P, et al. MRI findings of retrobulbar myxomaa case report. Clin Imaging. 2000;24:81-3.

9. Ducic I, Davison SP, Woll S, et al. Maxillary infraorbital myxoma: Reconstruction with vascularized temporal bone. Otolaryngol Head Neck Surg. 2003;128:426-7.

10. Lieb WE, Goebel HH, Wallenfang T. Myxoma of the orbit: A clinicopathologic report. Graefes Arch Clin Exp Ophthalmol.1990;228:28-32. 